\title{
JCNaR
}

\section{Synthesis of Polyurethane from Diphenyl Methane 4,4 Diisocyanate (Mdi) Polymerization with Hydroxilated Avocado Oil Polyol}

\author{
Herlince Sihotang ${ }^{1^{*}}$, Mimpin Ginting ${ }^{1}$, May Evi Ana Nadeak ${ }^{I}$ \\ 1* Department of Chemistry, Faculty of Mathematics and Natural Science, Universitas Sumatera Utara
}

\begin{abstract}
Polymerization between polyol and isocyanate compounds produces polyurethane in different forms. Polyol used in this study utilized spoiled avocado as the oil source for polyol to produce polyurethane. Avocado oil was epoxidized with formic acid ( $\mathrm{HCOOH})$ and $\mathrm{H}_{2} \mathrm{SO}_{4}$ catalyst at $40-45^{\circ} \mathrm{C}$ followed by hydrolysis reaction to produce polyol reaction. Next polyol was purified, and structure confirmation was done using FT-IR spectroscopy analysis. Polyol was then reacted with diphenylmethane 4,4 diisocyanate (MDI) with ratios of (polyol:MDI) 9:1; 8:2; 7:3; 6:4; and 5:5 (v/v) in a total volume of $10 \mathrm{~mL}$ with open air stirring at $40-45^{\circ} \mathrm{C}$ to produce polyurethane. Characterization for the form was observed visually followed by the determination of gel content, density and structure using FT-IR spectroscopy.The results of polyol from avocado oil reacted with diphenylmethane 4,4 diisocyanate for each of the mixing ratio to produce polyurethane is gel content of 74.63 to $99.80 \%$ where the higher MDI ratio is, the higher gel content becomes. Density determination from the polyurethane produced is between $0.1341 \mathrm{~g} / \mathrm{cm}^{3}$ to $0.7220 \mathrm{~g} / \mathrm{cm}^{3}$. FT-IR spectrometer analysis to polyurethane produced is marked with the peaks at 3400 $3300 \mathrm{~cm}^{-1}, 2270-1940 \mathrm{~cm}^{-1}, 1700-1600 \mathrm{~cm}^{-1}$ and $1590-1540 \mathrm{~cm}^{-1}$ wavenumbers which are the characteristic of urethane functional groups.
\end{abstract}

Keyword:Hydroxylation, MDI, Avocado oil, Polyol, Polyurethane

Received November 5, 2018| Revised December 19, 2018 | Accepted January 23, 2019

\section{Introduction}

Nowadays, the needs of polyurethane in the world, including Indonesia, experiences a dramatical increase. This is because polyurethane is used as the material for elastomer, adhesive, foam, paints and etc. Normally polyurethane is made of polyol from petroleum (Narine et al., 2007). However, petroleum is a non-renewable resource. Consequently, all related party is encouraged to find alternative resource to make polyol (Azmi, 2014).

\footnotetext{
*Corresponding author at:Department of Chemistry, Faculty of Mathematics and Natural Science, Universitas Sumatera Utara

E-mail address: sihotangherlince@yahoo.com
} 
Vegetable oil is one of the alternatives that can be used to make polyol for polyurethane. Polyol made of vegetable oil has its own superiority compared to that of petroleum, where it is abundant and a renewable resource. Indonesia has got an abundant source of vegetation resources, palm, soybean, sunflower, olive, corn, canola and nuts are several types of vegetable sources that produce oil. (Azmi, 2014). Those vegetable oils can be utilized to produce polyol for polyurethane. Unfortunately, there may be a competition for those materials to be consumed as food. Therefore, an alternative to other vegetation resources as material to make polyol is necessary, such as avocado (Persea americana Mill).

An avocado is a tropical and subtropical fruit with its growth spreads throughout provinces in Indonesia. A better handling of avocadoes is needed along with the increase of production to ensure the fruit is utilized. Avocadoes rot quickly and are not suitable to be kept for a long time (Moehd, 2003).Avocadoes produce oil rich of oleic acid, antioxidant and phytosterol (Requejo et al., 2003). The benefits of avocadoes make the fruits to be high in price. A big supply of avocadoes and the nature to rot easily have enabled processing and utilizing damaged avocadoes.In oleochemical industry, polyol made of vegetable oil that is rich of unsaturated fatty acids like oleic, linoleic and linolenic has been developed through epoxidation of unsaturated fatty acid double bonds as the raw material for polyurethane (Maznee et al., 2001).

Several past studies showed that epoxidation reaction of unsaturated fatty acid followed by hydrolysis can produce polyol derived from fatty acid. Ginting (2010) synthesized polyurethane compound from candlenut oil via epoxidation reaction of unsaturated fatty acid followed by hydrolysis and alkoxylation with glycerol as the source of polyol. Next, the compound is polymerized with TDI that led to the production of various form of polyurethane, from a soft solid like foam to a very firm solid. Azmi (2014) synthesized polyurethane compound though hydroxylation reaction of corn oil as the polyol source and it is then polymerized with TDI to produce rigid polyurethane.

In this study, epoxidation was done followed by hydrolysis of avocado oil with unsaturated fatty acid as its main composition. It contains of double bond to be converted as polyol. Next, polyol compound was reacted with MDI to produce polyurethane. Polyurethane formed was analyzed using FT-IR spectroscopy and gravimetry for density and gel content.

\section{Materials and Methods}

The equipment used in this research was: laboratory glassware, analytical balance, thermometer, hotplate and magnetic stirrer, aluminium container, desiccator, FT-IR spectrophotometer. The material used in this research was: avocado oil, methylene diphenyl diisocyanate, toluene, bleaching earth, hydrogen peroxide, dichloromethane, n-hexane, benzene, $\mathrm{NaOH}$ pellets, anhydrous calcium chloride, anhydrous sodium sulfate, phosphoric acid and diethyl ether. 


\subsection{Avocado Oil Extraction}

Modification of the commonly used extraction method was done in order to extract and purify avocado oil (Ketaren, 2008).

\subsection{Synthesis of Polyol from Avocado Oil}

$100 \mathrm{ml}$ of formic acid ( $\mathrm{HCOOH} 90 \%$ ) was poured into $250 \mathrm{ml}$ three neck flask. $50 \mathrm{ml}$ of $\mathrm{H}_{2} \mathrm{O}_{2}$ $30 \%$ was added. While stirring at $40-45^{\circ} \mathrm{C}$ for 1 hour, $3 \mathrm{ml}$ of $\mathrm{H}_{2} \mathrm{SO}_{4}$ was added. Then $60 \mathrm{ml}$ of avocado oil was added and stirred for 2 hours at $40-45^{\circ} \mathrm{C}$. The product was left for one night and it was stirred with $10 \mathrm{ml}$ of $\mathrm{NaOH} 10 \%$ and evaporated. The precipitate was dissolved in $150 \mathrm{ml}$ of diethyl ether. Ether layer was washed with $25 \mathrm{ml} \mathrm{NaOH} 2 \mathrm{M}$ and followed by aquadest for 3 times. The washing result was dried using anhydrous $\mathrm{Na}_{2} \mathrm{SO}_{4}$ and filtered. The filtrate was evaporated to get polyol avocado oil as precipitate. Iodine value test and FT-IR spectroscopy were conducted.

\subsection{Synthesis of Polyurethane}

$20 \mathrm{ml}$ of dichloromethane was put into a $190 \mathrm{ml}$ aluminium container. Polyol from avocado oil was added and the mixture was heated at $45^{\circ} \mathrm{C}$. MDI was added with stirring with a ratio of polyol $:$ MDI $=9: 1,8 ; 2,7: 3,6: 4$ and 5:5 (v/v) with a total volume of $10 \mathrm{ml}$. Any changes occurred were observed and the gel content and density were analyzed using gravimetry and FT-IR spectroscopy was conducted.

\section{Result and Discussion}

\subsection{Avocado Oil Extraction and Bleaching Result}

About $46.51 \%$ of oil was obtained from the extraction of avocado oil from avocado fruit. Degumming of extracted avocado oil was done by adding phosphoric acid to precipitate sap or slime like peptide compounds. Bleaching earth was added to produce a clearer oil as the pigment in the oil was absorbed during the bleaching process. In iodine value test, 84.13 shows double bonds existence that can be epoxidized to make polyol. Avocado oil FT-IR spectroscopy gives absorbance spectra peaks at the wavenumbersshown in Figure 3.1. 


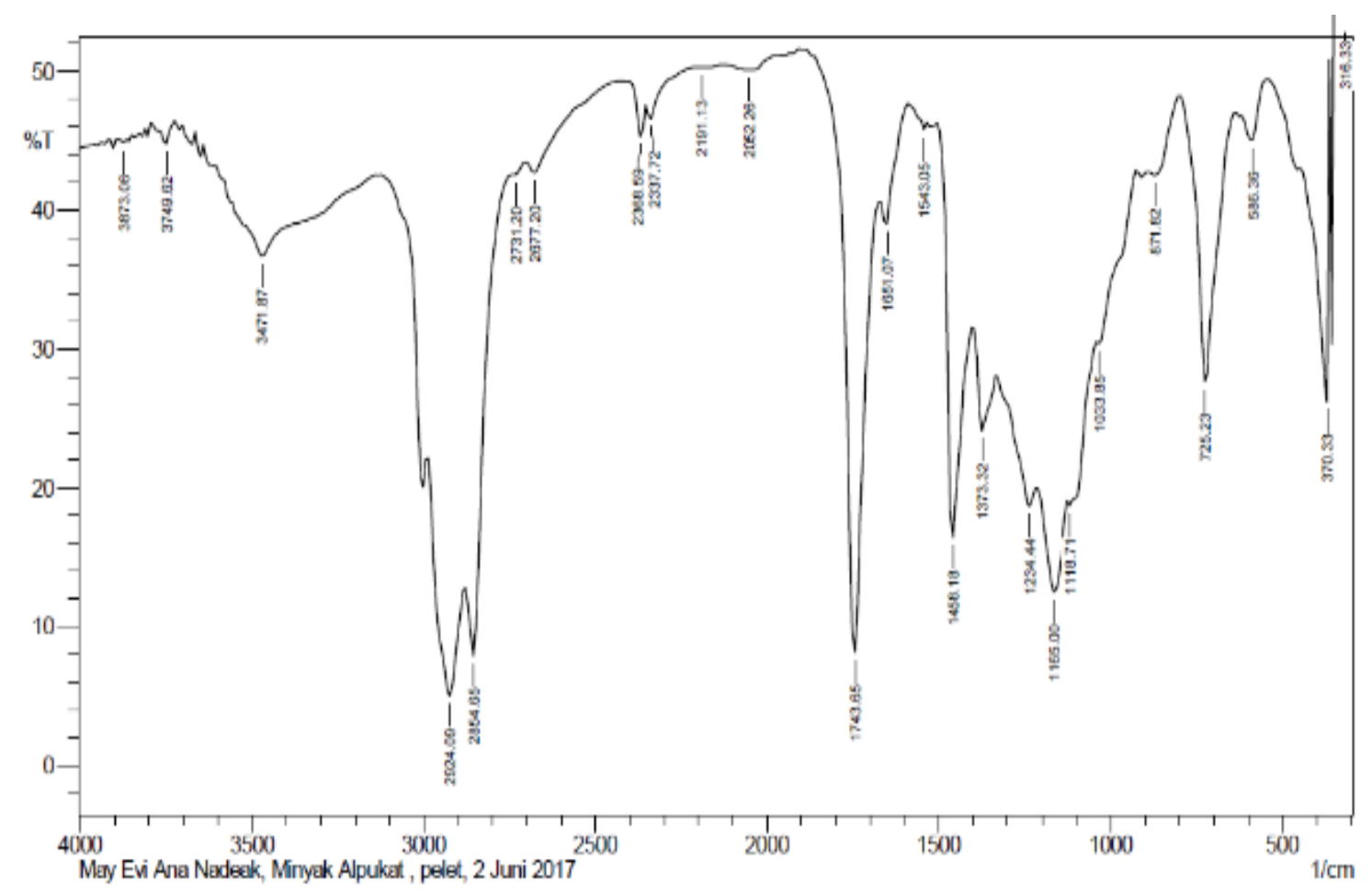

Figure 3.1. Avocado oil FT-IR spectra

\subsection{Fatty Acid Composition}

The chromatogram of gas chromatography is shown in Figure 3.2. Fatty acid composition of fatty acid and the percentage can be seen on Table 3.1. The results show that the fatty acid consists of odd total number of carbons. This is due to decarboxylation process in fatty acid biogenesis that causes reduction of carbon atom in fatty acid. 


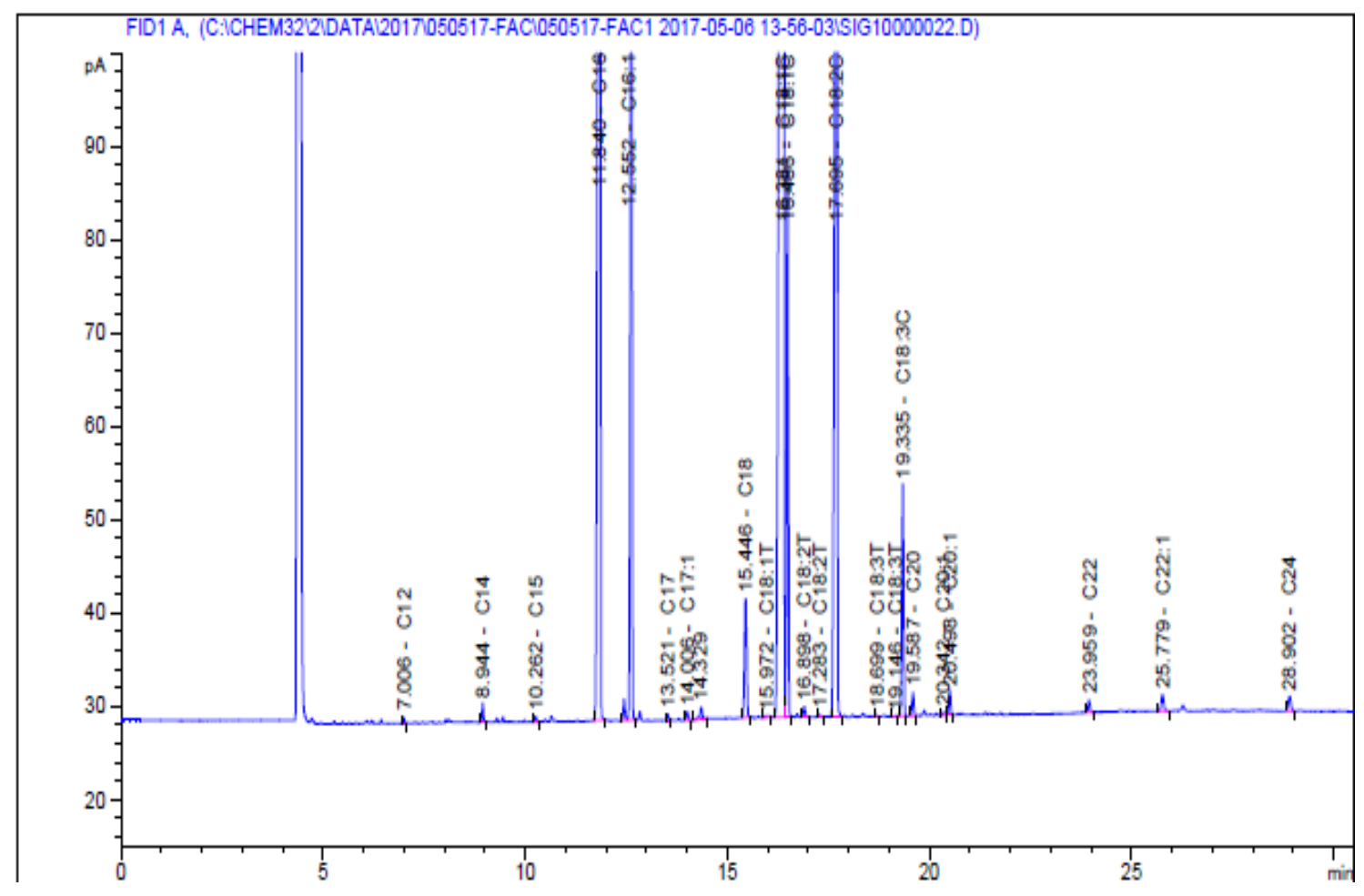

Figure 3.2.Chromatogram of fatty acid composition

Table 3.1. Fatty acid composition of avocado oil and the percentage

\begin{tabular}{lc}
\hline Fatty Acid & Total (\%) \\
\hline Lauric Acid (C12:0) & 0.03 \\
\hline Myristic Acid (C14:0) & 0.11 \\
\hline Pentadecanoate Acid (C15:0) & 0.03 \\
\hline Palmitic Acid (C16:0) & 23.87 \\
\hline Palmitoleic Acid (C16:1) & 6.46 \\
\hline Heptadecanoate Acid (C17:0) & 0.04 \\
Heptadecanoleate Acid (C17:1) & 0.06 \\
\hline Stearic Acid (C18:0) & 1.12 \\
\hline Trans Oleic Acid (C18:1T) & 0.03 \\
\hline Cis Oleic Acid (C18:1C) & 50.62 \\
\hline Trans Linoleic Acid (C18:2T) & 0.10 \\
\hline Cis Linoleic Acid (C18:2C) & 14.72 \\
\hline Trans Linolenic Acid (C18:3T) & 9.56 \\
\hline Cis Linolenic Acid (C18:3C) & 1.88 \\
\hline Arachidonic Acid (C20:0) & 0.17 \\
\hline Dodecanoleic Acid (C20:1) & 0.23 \\
\hline Behenic Acid (C22:0) & 0.09 \\
\hline Dodidecanoleic Acid (C22:1) & 0.17 \\
\hline Tetradidecanoic Acid (C24:0) & 0.16 \\
\hline
\end{tabular}




\subsection{Synthesis of Polyol from Avocado Oil}

Avocado oil was epoxidized with performic acid with $\mathrm{H}_{2} \mathrm{SO}_{4}$ catalyst and refluxed at $45^{\circ} \mathrm{C}$. Next, it was hydrolyzed to produce polyol compound. The formation of polyol compound, in the condition where epoxidation process and hydrolysis ran perfectly, hypothetically oleic (C18:1) bound as glyceride produces diol. Based on this hypothesis, epoxidation reaction of avocado oil with performic acid and hydrolysis produces polyol compound.

Iodine value test of polyol and avocado oil were 6.26 and 84.13 respectively which show that there is a break of $\pi$ bond in unsaturated fatty acid of avocado oil. FT-IR spectroscopy analysis with its vibration peak is shown in Figure 3.3. The signal at $3441 \mathrm{~cm}^{-1}$ wavenumber shows $-\mathrm{OH}$ stretching, while $1172 \mathrm{~cm}^{-1}$ shown a secondary -OH vibration. Then the disappearance of 3089 and $1651 \mathrm{~cm}^{-1}$ proves that $\pi$ bond was broken $\left(\mathrm{C}-\mathrm{H} \mathrm{sp}{ }^{2}\right.$ from $\left.-\mathrm{CH}=\mathrm{CH}-\right)$ of unsaturated fatty acid. $1743 \mathrm{~cm}^{-1}$ wavenumber is a vibration of $\mathrm{C}=\mathrm{O}$ functional group. $1458-1373 \mathrm{~cm}^{-1}$ wavenumbers are bending vibrations of $\mathrm{C}-\mathrm{H} \mathrm{sp}$. The absorbance band of $725 \mathrm{~cm}^{-1}$ wavenumber is a hydrocarbon vibration of a long chain alkyl $\left(\mathrm{CH}_{2}\right)_{\mathrm{n}}$

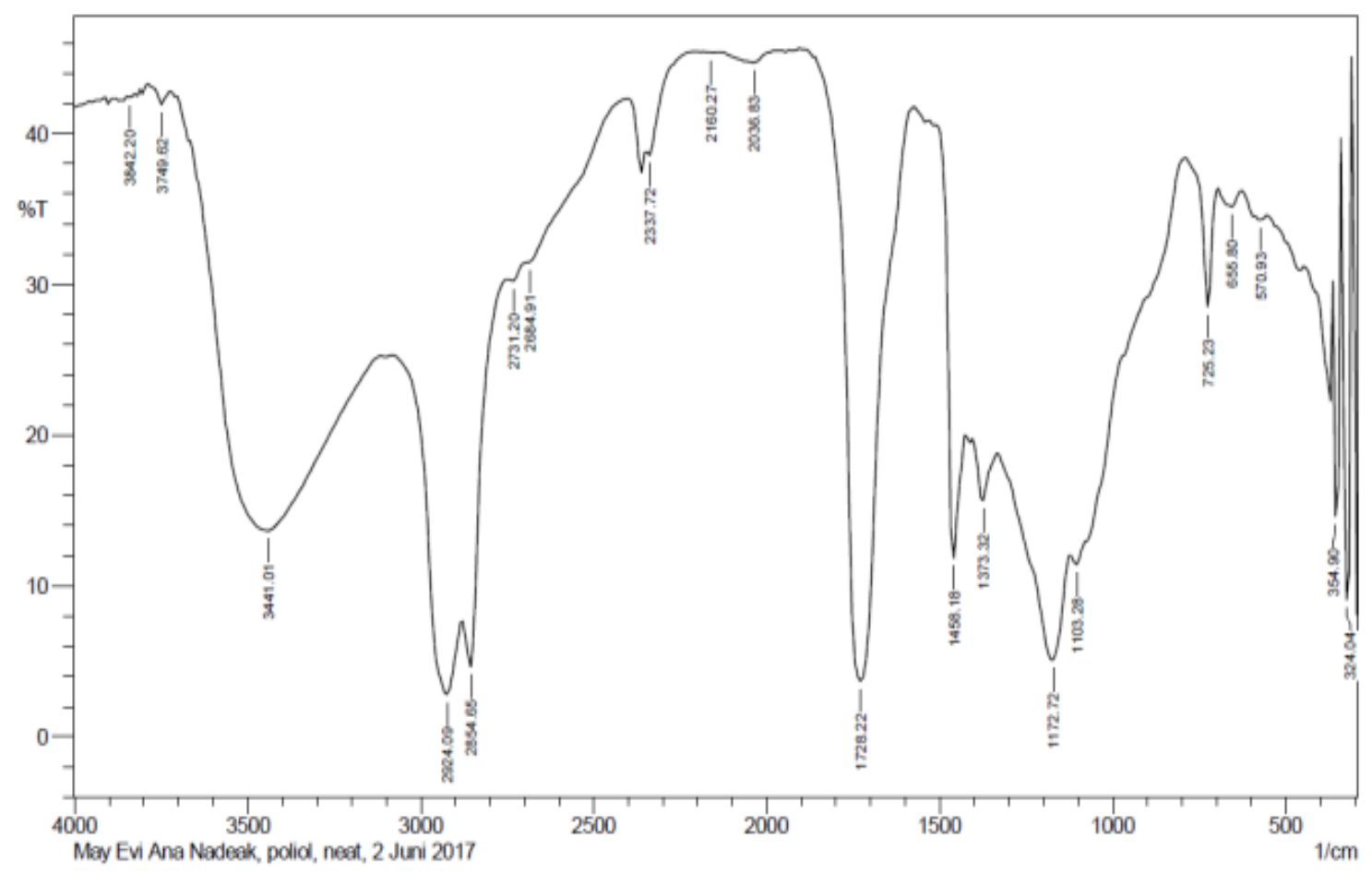

Figure 3.3. FT-IR spectrum of avocado oil polyol

\subsection{The Synthesis of Polyurethane}

Physical Changes of Polyurethane. Visual analysis shows that polyurethane produced from the polymerization between avocado oil polyol and methylene diphenyl diisocyanate is solid and hard. Polyurethane formed describes that the structure pattern of polyol hydrocarbon used 
affects the shape of polyurethane. The result of physical properties and gel content analysis are shown in Table 3.1.

Table 3.1 The characteristic of polyurethane from avocado oil polymerization with MDI

\begin{tabular}{cccc}
\hline Polyol & $\begin{array}{c}\text { Polyol:MDI ratio } \\
(\mathrm{v} / \mathrm{v})\end{array}$ & Gel Content $(\%)$ & $\begin{array}{c}\text { Polyurethane } \\
\text { Physical } \\
\text { Condition }\end{array}$ \\
\hline Avocado Oil & $9: 1$ & 74.63 & Soft \\
Polyol & $8: 2$ & 83.86 & Hard \\
& $7: 3$ & 92.13 & Hard \\
& $6: 4$ & 98.12 & Hard \\
$5: 5$ & 99.80 & Hard \\
\hline
\end{tabular}

Polyurethane Gel Content. The polyurethanes formed from polyol:MDI ratio of 9:1 to 5:5 $(\mathrm{v} / \mathrm{v})$ gave various gel contents with an increasing trend (Figure 3.3), which shows that there are different cross-links bonding. This condition happens as polyol with MDI polymerization produces low degree polymer based on the stoichiometry. A lot of - $\mathrm{OH}$ functional group from polyol monomers are free and they are not in the reaction. With the increase of MDI ratio used in the polymerization, gel content rises as $-\mathrm{OH}$ groups from polyol form a more perfect polyurethane links. The objectives of gel content analysis is to know the degree of cross-links. Gel is a solid that consists of at least two components that have formed cross-link bondage and is insoluble. Therefore, the higher gel content is, the less soluble polyurethane is in organic solvent like benzene, toluene, acetone or other solvents. Furthermore, it has higher durability.

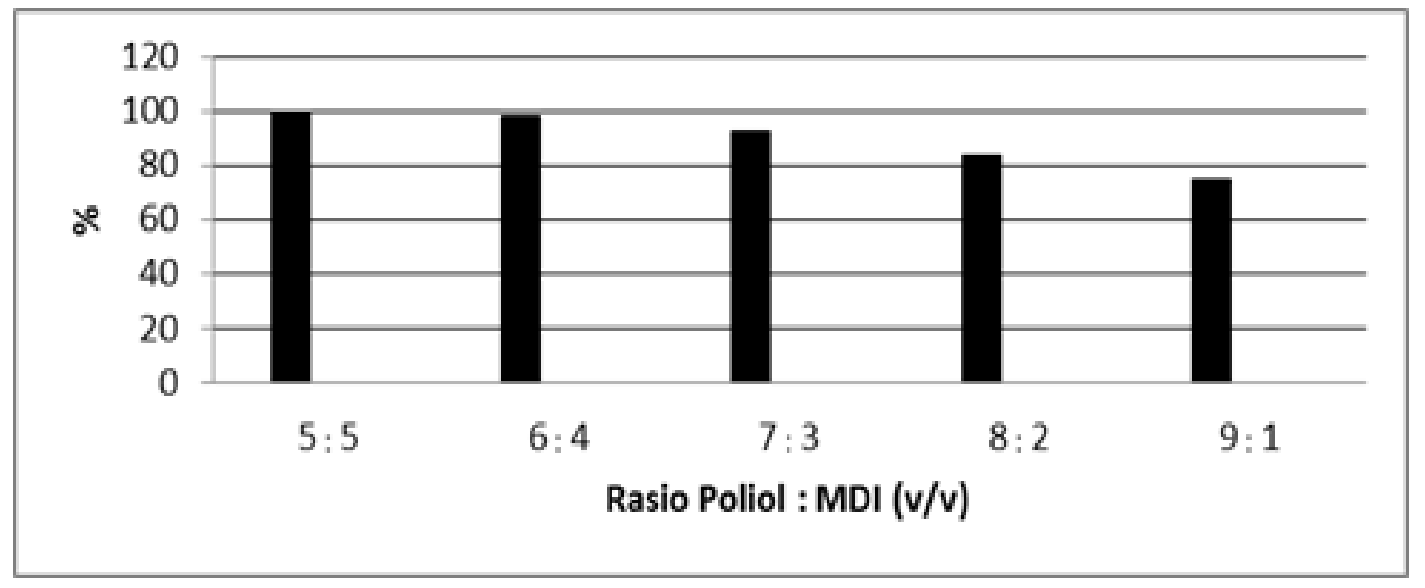

Figure 3.4. Gel content in polyurethane from polyol and MDI polymerization of different ratio

Polyurethane Density. Polyurethane synthesized from avocado oil hydroxylation with isocyanate has different forms. Moreover, it has got different density of every polyol:MDI ratio of 9:1 (v/v) to 5:5 (v/v) as shown in Table 3.2. The density of cross-link is higher with the increasing amount of MDI in the mixture.

Table 3.2 Density of polyurethane from avocado oil polyol with MDI in various ratio 


\begin{tabular}{ll}
\hline Polyol : MDI Ratio & Density $\left(\mathbf{g r} / \mathbf{c m}^{\mathbf{3}}\right)$ \\
\hline $\mathbf{9 : 1}$ & 0.1341 \\
$\mathbf{8 : 2}$ & 0.1588 \\
$\mathbf{7 : 3}$ & 0.2589 \\
$\mathbf{6 : 4}$ & 0.3937 \\
$\mathbf{5 : 5}$ & 0.7220 \\
\hline
\end{tabular}

FT-IR Spectroscopy Analysis Spectrum. The characterization of synthesized polyurethane from polyol and MDI with ratios of 9:1, 8:2, 7:3, 6:4 and 5:5 (v/v) using FT-IR spectroscopy produced spectra that can be seen in Figure 3.5 (a), (b), (c), (d) and (e) respectively.

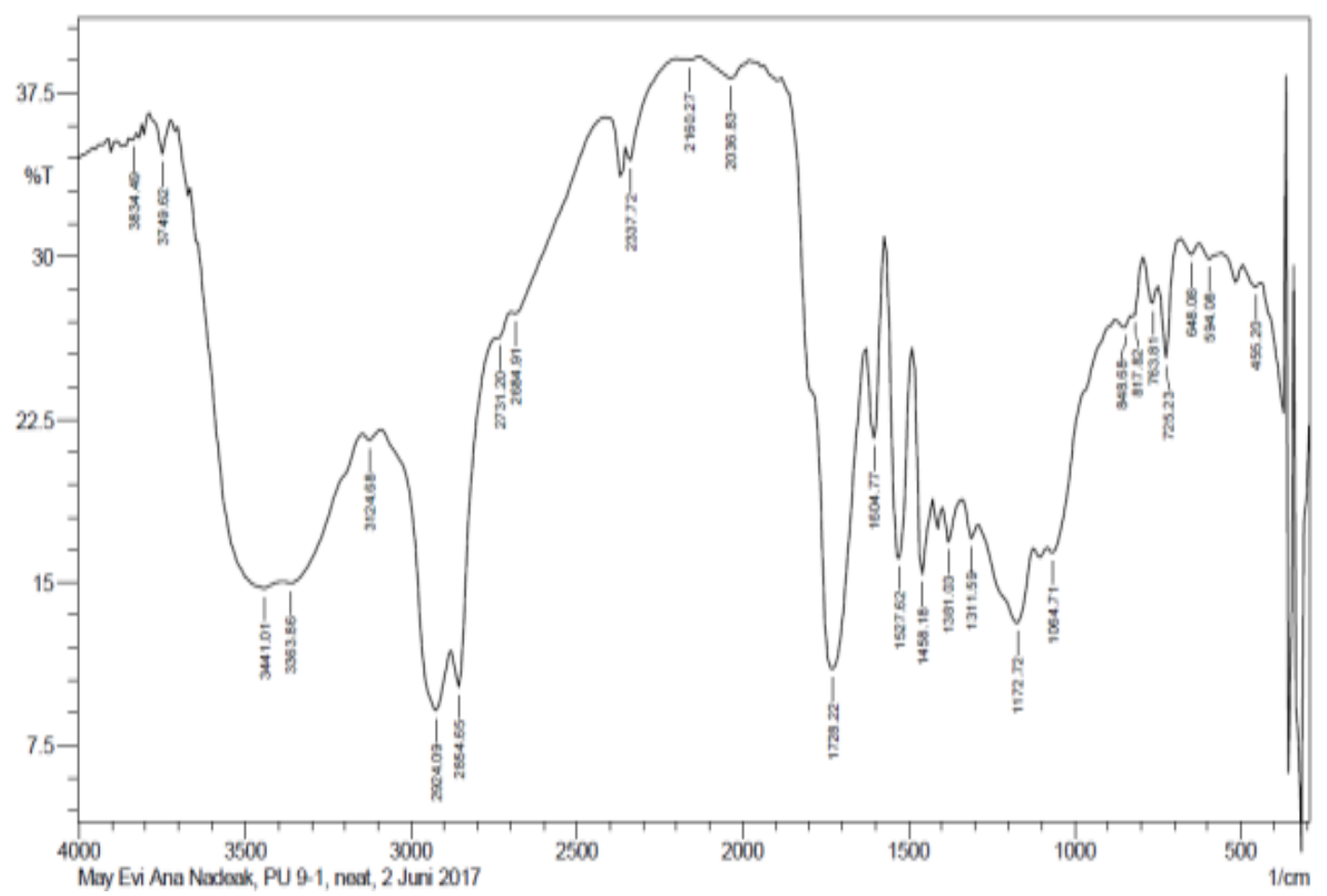

Figure 3.5 (a) FT-IR spectrum of polyol:MDI = 9:1 (v/v) polymerized polyurethane 


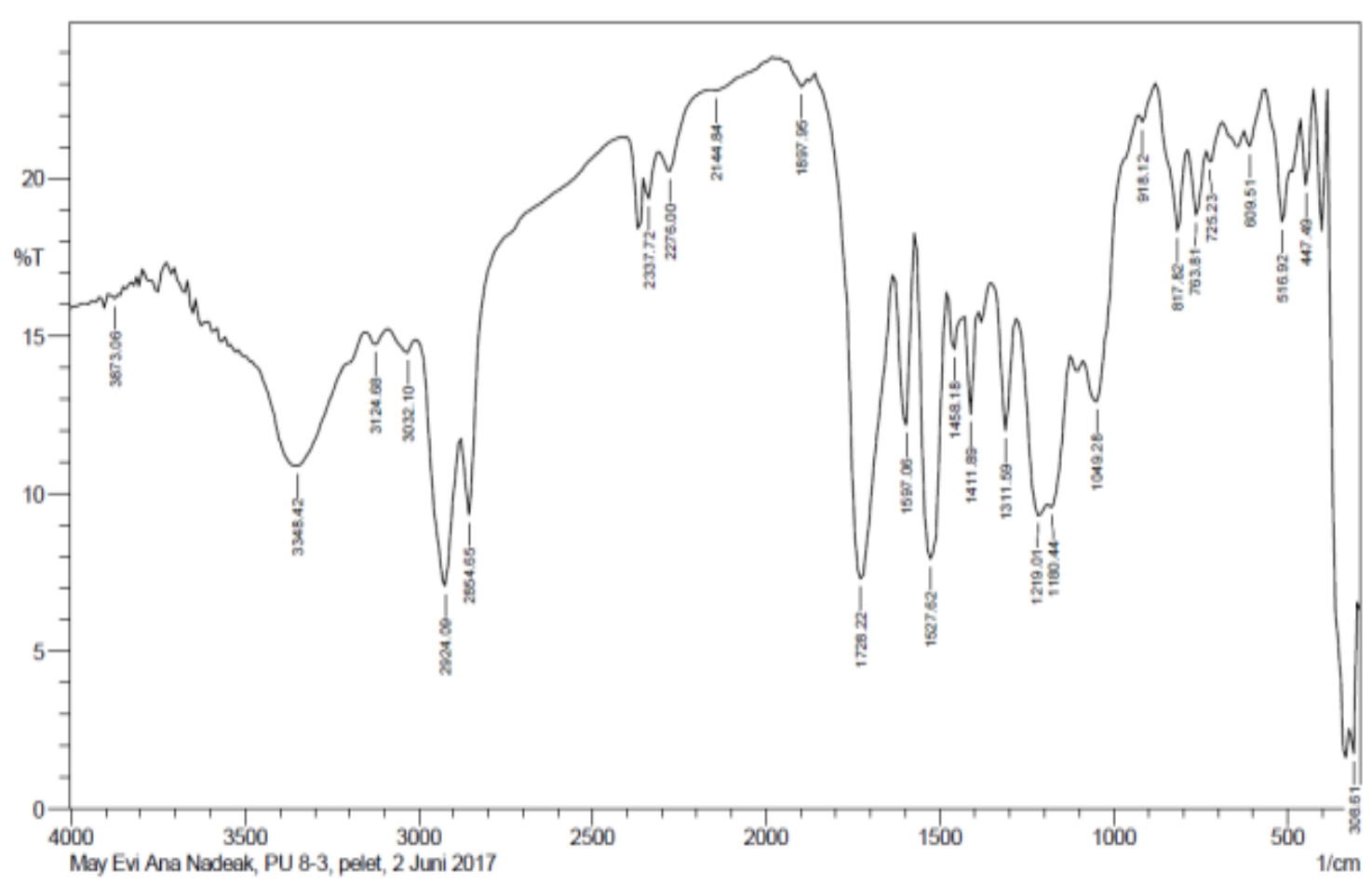

Figure 3.5 (b) FT-IR spectrum of polyol:MDI = 8:2 (v/v) polymerized polyurethane

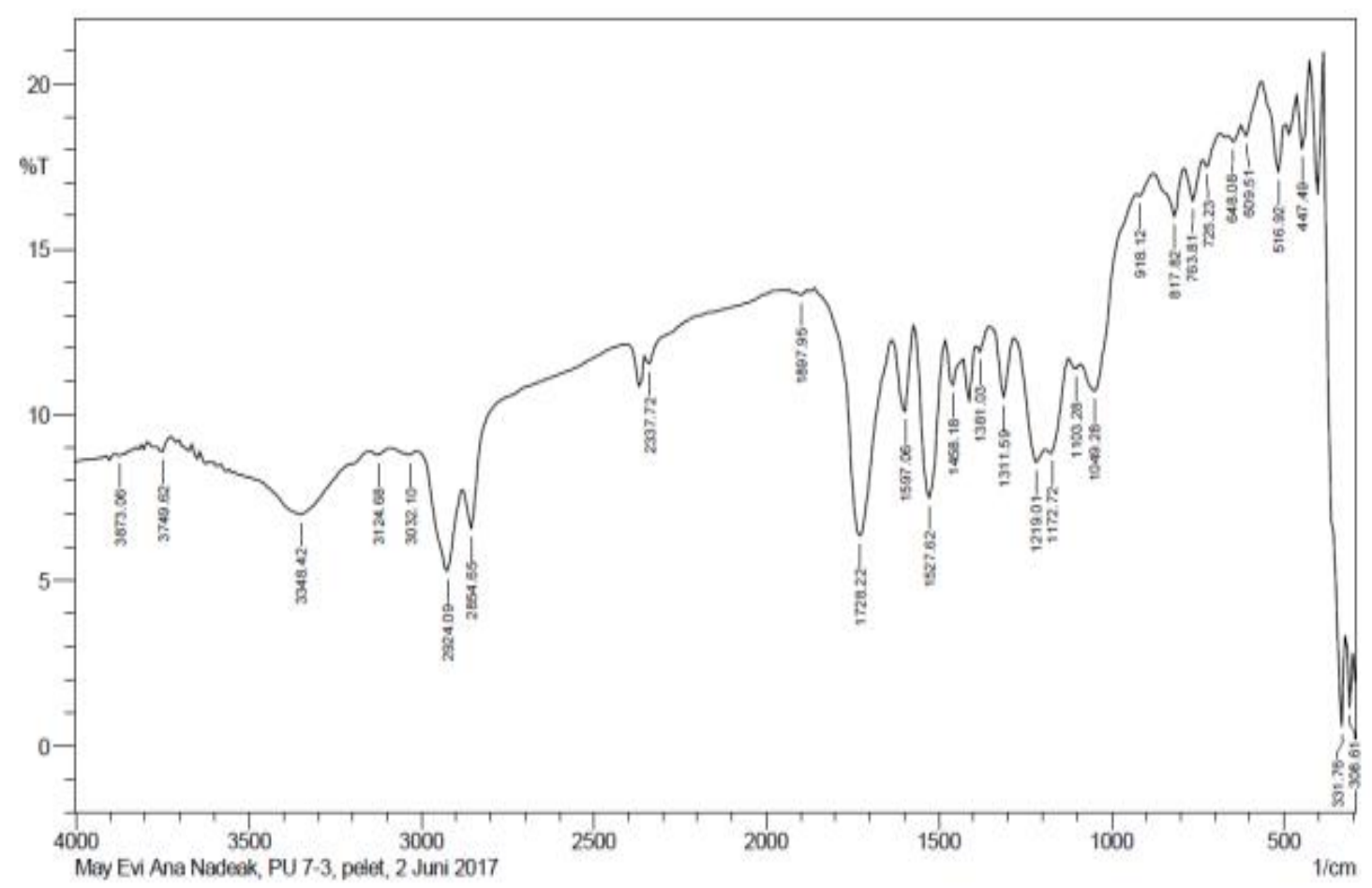

Figure 3.5 (c) FT-IR spectrum of polyol:MDI = 7:3 (v/v) polymerized polyurethane 


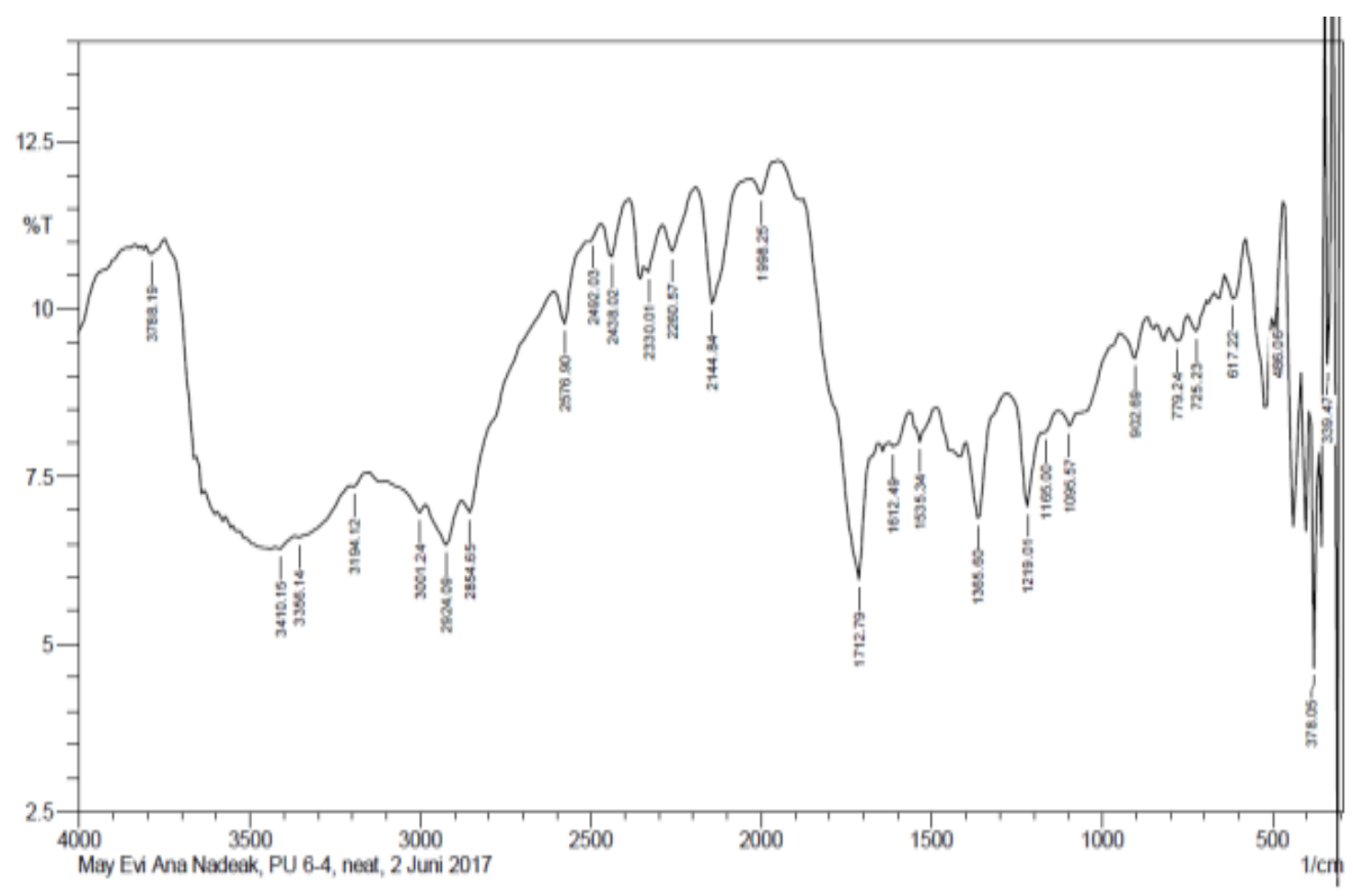

Figure 3.5 (d) FT-IR spectrum of polyol:MDI = 6:4 (v/v) polymerized polyurethane

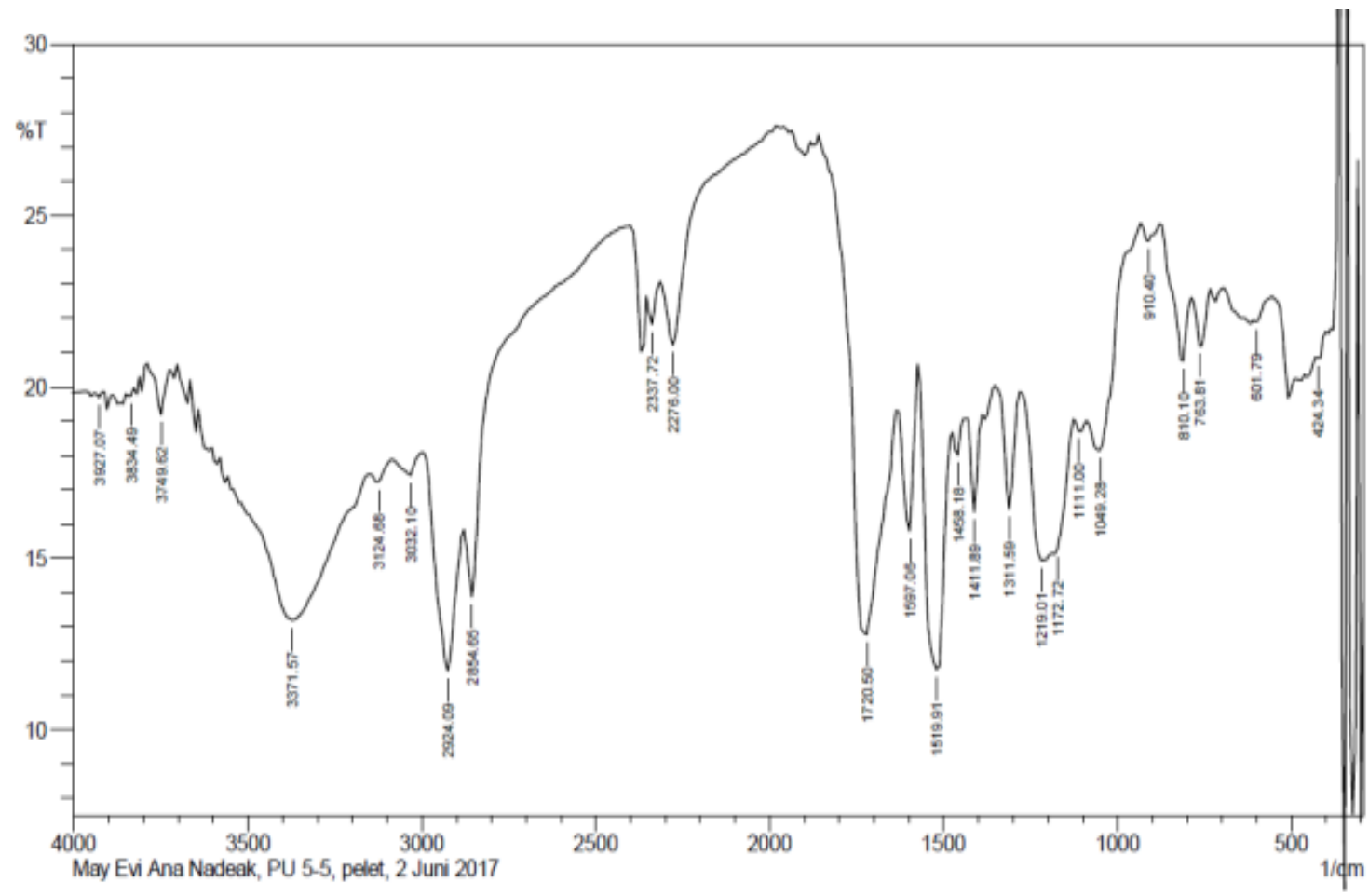

Figure 3.5 (e) FT-IR spectrum of polyol:MDI = 5:5 (v/v) polymerized polyurethane

FT-IR spectrum analysis of every ratio normally shows a similarity, which in this case is the formation of urethane functional groups depicted in 3100-3500 $\mathrm{cm}^{-1}$ wavelength $(\mathrm{N}-\mathrm{H}$ stretching), $1700-1750 \mathrm{~cm}^{-1}$ (stretching) and 1000-1300 $\mathrm{cm}^{-1}$ (stretching C-O-C) as shown in Table 3.3. However, in 9:1 and 8:2 ratios, there is a non-reactive hydroxyl group at 3600-3650 $\mathrm{cm}^{-1}$. This is caused by the number of polyol used has more hydroxyl groups than the available 
isocyanate group. Mixing ratio between polyol and MDI for 4:6 to 1:9 ratios were not done. With excess MDI, isocyanate that is yet reacted will react with $-\mathrm{OH}$ group from $\mathrm{H}_{2} \mathrm{O}$ in air. Furthermore, isocyanate is relatively higher in price.

Table 3.3. Table of functional groups wavelength for polyurethane with various ratios

\begin{tabular}{cccccc}
\hline $\begin{array}{c}\text { Wavelength } \\
\left(\mathrm{cm}^{-1}\right)\end{array}$ & $5: 5$ & $6: 4$ & $7: 3$ & $8: 2$ & $9: 1$ \\
\cline { 2 - 6 } & 3371 & 3356 & 3348 & 33348 & 3361 \\
\hline Stretching N-H & 1516 & 1535 & 1527 & 1527 & 1527 \\
\hline Bending N-H & $2854-2924$ & $2854-2924$ & 2854 & $2854-2924$ & $2854-2924$ \\
\hline Stretching C-Hsp & & \multicolumn{5}{c}{ Polyol:MDI } \\
\hline Bending C-Hsp & $1411-1458$ & 1365 & $1381-1458$ & $1411-1458$ & $1411-1458$ \\
\hline Vibration N=C=O & 2276 & 2276 & 2337 & 2276 & 2279 \\
\hline Vibration C=O & 1720 & 1712 & 1728 & 1728 & 1728 \\
\hline Vibration $\mathrm{C}=\mathrm{C}$ & 1597 & 1612 & 1597 & 1597 & 1604 \\
\hline Vibration $\mathrm{C}=\mathrm{O}=\mathrm{C}$ & 1172 & 1165 & 1172 & 1180 & 1172 \\
\hline Vibration $\left(\mathrm{CH}_{2}\right) \mathrm{n}$ & 763 & 725 & 722 & 722 & 725 \\
\hline
\end{tabular}

\section{Conclusion}

Based on the research done, it can be concluded as follow: avocado oil obtained from rotten avocado fruits can be epoxidized with performic acid and sulfuric acid as catalyst followed by hydrolysis reaction to produce polyol compound. Next, polyol is reacted with MDI to produce polyurethane. Polymerization of avocado oil polyol with diphenylmethane 4,4'-diisocyanate (MDI) produces polyurethane in which with a different ratios of mixture between polyol and MDI $=9: 1,8: 2,7: 3,6: 4$ and 5:5 gave different gel content. The highest gel content, 99.8\%, and density, $0.722 \mathrm{gr} / \mathrm{cm}^{3}$ is found in the ratio of 5:5 (v/v) polyol : MDI respectively.

\section{Acknowledgements}

To head laboratory of Organic Chemistry Faculty of Mathematics and Natural Sciences, Universitas Sumatera Utara who provides the facilities for this research, the team members who have worked together for this study and to head of department who provides the facilities to do the research.

\section{References}

Azmi, R., 2014. Sintesis Poliuretan dari Asam Lemak Terepoksidasi Minyak Jagung Melalui Proses Hidroksilasi di Pusat Penelitian Kelapa Sawit, Skripsi Sarjana FMIPA USU, Medan.

Ginting, M. 2010. Pemanfaatan Hasil Hidrolisis dan Alkosilasi dengan Gliserol dari Epoksida Minyak Kemiri sebagai Sumber Poliol untuk Pembuatan Poliuretan,Disertasi Program Studi Doktor Ilmu Kimia FMIPA USU, Medan.

Ketaren,S, 2008, Pengantar Teknologi Lemak dan Minyak Pangan, UI-Press, Jakarta.

Maznee, T.N., Norin, Z.K.S., Ooi, T.L, Salmiah, A and Gan, L.H., 2001, Effects Of Additives On Palm-Based Polyurethan Foams, Journal of Oil Palm Research, Vol.13(2), pp.7-15.

Moehd, B.K., 2003,Alpukat : Budidaya danPemanfaatannya, Kanisius, Yogyakarta. 
Narine, S.S., Kong, X., Bouzidi, L., and Sporas, P., 2007, Physical Properties of Polyurethanes Produced from Polyols from Seed Oils: I. Elastomers, J.Am.Oil.Chem.Soc.Vol. 84, pp.5563.

Requejo, A. M., Ortega, R. M., Robles, F., Navia, B., Faci, M., and Aparicio, A., 2003, Influence of nutrition on cognitive function in a group of elderly, independently living people, Europ. J. Clinic. Nutri., Vol. 57, pp. S54-S57. 